\title{
Morphometry of the stone crayfish (Austropotamobius torrentium) in the Czech Republic: allometry and sexual dimorphism
}

\author{
P. Vlach ${ }^{(1), \star}$, L. Valdmanová(1)
}

Received December 27, 2014

Revised May 11, 2015

Accepted May 17, 2015

\section{ABSTRACT}

Key-words: stone crayfish, morphometry, carapace, abdomen, chelae, allometric growth

\begin{abstract}
The stone crayfish Austropotamobius torrentium (Schrank, 1803) is a native crayfish species in the Czech Republic. Biometric analysis of this crayfish species in the Czech Republic has not been performed up to now. The aim of this paper is to provide these data. The maximum observed body length was $94.8 \mathrm{~mm}$ in females and $103.6 \mathrm{~mm}$ in males. As the main characters of sexual dimorphism were observed, males had the carapace and chelae relatively longer in relation to the total body length and the carapace length respectively, while females showed longer rostro-cervical part of the carapace and wider abdomen. The chelae width/length ratio was larger in females; the chelae width/length ratios and abdomen width differed between sexes in both adults and juveniles. Most of observed body parts grow allometrically. The positive allometry was found in the following length relations: the carapace length in males only, carapace width, and abdomen width (all related to the carapace length) in females, and chelae width/length ratio in females. Negative allometric growth was recorded in the length of the rostro-cervical part of the carapace, chelae width, and chelae height in males.
\end{abstract}

\section{RÉSUMÉ}

Morphométrie de l'écrevisse (Austropotamobius torrentium) en République tchèque : allométrie et dimorphisme sexuel

Mots-clés:
écrevisse
de torrent,
morphométrie,
carapace,
abdomen,
pinces,
croissance
allométrique

Mots-clés :

L'écrevisse Austropotamobius torrentium (Schrank, 1803) est une espèce d'écrevisse indigène de la République tchèque. L'analyse biométrique de cette espèce d'écrevisse n'a pas été effectuée jusqu'à présent en République tchèque. Le but de ce document est de fournir ces données. La longueur maximale observée du corps était de 94,8 mm chez les femelles et 103,6 mm chez les mâles. On a observé les paramètres principaux du dimorphisme sexuel ; les mâles avaient la carapace et les pinces relativement plus longues par rapport à la longueur totale du corps et à la longueur de la carapace, respectivement, tandis que les femelles ont montré une partie rostro-cervicale de la carapace plus longue et un abdomen plus large. Le rapport largeur/longueur des pinces était plus grand chez les femelles; le ratio largeur/longueur des pinces et la largeur de l'abdomen différaient entre

(1) Center of Biology, Geosciences and Envigogika, Faculty of Education of the University of West Bohemia, Klatovská 51, 30619 Plzen, Czech Republic

* Corresponding author: vlach.pavel@mybox.cz 
les sexes, chez les adultes et chez les jeunes. La plupart des parties du corps observées ont un développement allométrique. L'allométrie positive a été trouvée dans les relations de longueur suivantes : la longueur de la carapace chez les mâles seulement, la largeur de la carapace, et la largeur de l'abdomen (toutes deux liées à la longueur de la carapace), et le rapport largeur/longueur de la pince chez les femelles. La croissance allométrique négative a été mesurée dans la longueur de la partie rostro-cervicale de la carapace, la largeur des pinces, et la hauteur des pinces chez les mâles.

\section{INTRODUCTION}

The stone crayfish Austropotamobius torrentium (Schrank, 1803) is an European indigenous crayfish species. Its range covers 20 countries in the Danube and Elbe watersheds in Southeastern and Central Europe (Kouba et al., 2014). The stone crayfish has an IUCN "data deficient" status and is listed among priority species in the Habitats Directive (European Communities, 1992).

In the Czech Republic, only two indigenous crayfish species have been reported and both species have the status of "critically endangered species" and are protected by law (114/1992).

While the distribution of the noble crayfish Astacus astacus (Linnaeus, 1758) is relatively widespread, the stone crayfish occurs only rarely and currently inhabits approximately 45 streams (Vlach et al., 2009a). The latter species has been studied mainly in the last two decades. The first reviews of reported localities and ecology in the Czech Republic was provided by Duuriš et al. (2001) and Kozák et al. (2002). Actual data based on detailed field researches were recently provided on distribution by Vlach et al. (2009a), and on habitat parameters by Vlach et al. (2009b, 2012), and reviewed also in books on crayfish biology (Štambergová et al. , 2009; Kozák et al., 2013, 2015). Recently, the origin of the stone crayfish populations in the Czech Republic has been studied (Pešek, 2013). Whereas most populations belong to the Elbe watershed, a few streams in south-west are in the Danube water basin, and there also is a distant population in the north-east Bohemia, probably translocated by human from the Balkan Peninsula (Pešek, 2013).

The morphology of crayfish of the genus Austropotamobius has often been studied with the common aim of identifying morphological differences between the sexes or ontogenetic stages. This traditional morphometric attempt have used e.g. by Grandjean et al. (1997), Sint et al. (2005) or Zekić et al. (2013) in A. pallipes or by Pârvulescu (2010), Sint et al. (2005) and partially by Maguire and Klobučar (2009) in A. torrentium. Other studies have focused on finding a geographical gradient in morphology or differences among separated populations. Whereas Grandjean and Souty-Grosset (2000) assumed traditional biometrics as useless for that purposes, Sint et al. (2005) have been able to find some geographical gradient in morphology of $A$. pallipes using linear measurements of the carapace. Scalici et al. (2010) underlined major ontogenetic changes in the carapace shape and marked them as well as sexual dimorphism as confound elements affecting interpretation of such a comparative studies.

Only few published works have considered allometry as the phenomenon of uneven growth of some morphological features, changing the shapes and measurements of crayfish under different etho-ecological and physiological demands on certain ontogenetic stages (Scalici et al., 2010). There are two conceptual frameworks of allometry (Klingenberg, 1998). The first attitude has been defined by Huxley and Teissier (see Gayon, 2000) as the relationships between body measurements and changes in the relative proportions of these measurements with changes in absolute size (Gayon, 2000). Streissl and Hödl (2002) have focused on allometry of some measurements in A. torrentium. Another point of view expresses allometry as changes in measurements and shapes between juveniles and adults (Klingenberg, 1998; Bertocchi et al., 2008). 


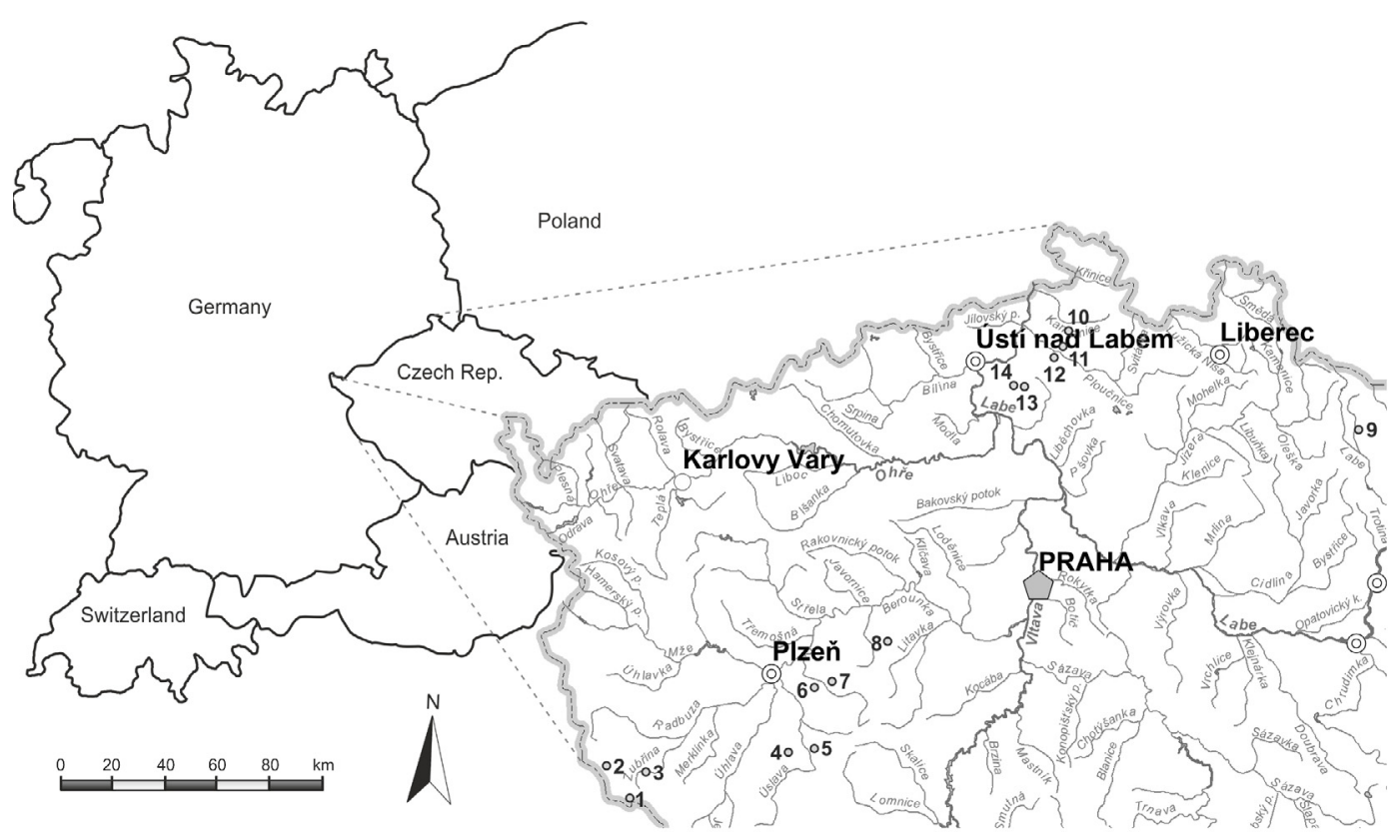

\section{Figure 1}

Map of the Czech Republic showing positions of the examined streams: 1. Medvědí brook, 2. a left tributary of Novosedlský brook, 3. Zubřina, 4. Chocenický brook, 5. Přešínský brook, 6. Rakovský brook, 7. Chejlava, 8. Bzovský brook, 9. Luční brook (Giant Mountains), 10. Huníkovský brook, 11. Vrbový brook, 12. Valdecký brook, 13. Luční brook (Bohemian Highlands), 14. Trojhorský brook.

To avoid an incapability of traditional linear morphometry in an ability to distinguish between size and shape variations, new geometric morphometric approach considering both measurements and shapes is recently used. Based on this attempt, Bertocchi et al. (2008) have showed little differences between two possible genetic lineages representing different haplotypes in A. pallipes in Italy. Moreover, Scalici et al. (2010) have been able to describe an external carapace morphology in $A$. pallipes, which is not affected by sexual differences and not or little influenced by different ontogenetic stages.

However, most of the above mentioned studies are focused on A. pallipes and only few biometric analyses concerning $A$. torrentium have been performed up to now (e.g. Streissl and Hödl, 2002; Maguire et al., 2005; Sint et al., 2005; Maguire and Klobučar, 2009; Pârvulescu, 2010). Consequently, the aim of this study is to supply missing data about the morphology of the stone crayfish, including on the sexual dimorphism, and the evaluation of allometric growth of selected size parameters. The prime importance of the presented work based on a large numbers of evaluated individuals is to perceive, despite belonging to geographically and genetic isolated populations, changes in length relations within A. torrentium as the species in the Czech Republic.

\section{MATERIAL AND METHODS}

The data used for this study were collected in two sampling campaigns between May and October in 2013 and 2014. For this study, 14 brook localities were chosen (see Table I). These localities correspond with overall distribution of the stone crayfish in the Czech Republic (see Figure 1). The localities were in small streams and had substrates predominantly gravel, stone, till or partially regulated bottoms. For further characteristics of the examined localities see Vlach et al. (2009a).

Crayfish were caught by searching through all possible refuges (e.g. turning stones over) by hand and hand netting. All individuals were kept in plastic containers and then measured by mechanical callipers accurate to $0.1 \mathrm{~mm}$. The following morphological characteristics were 


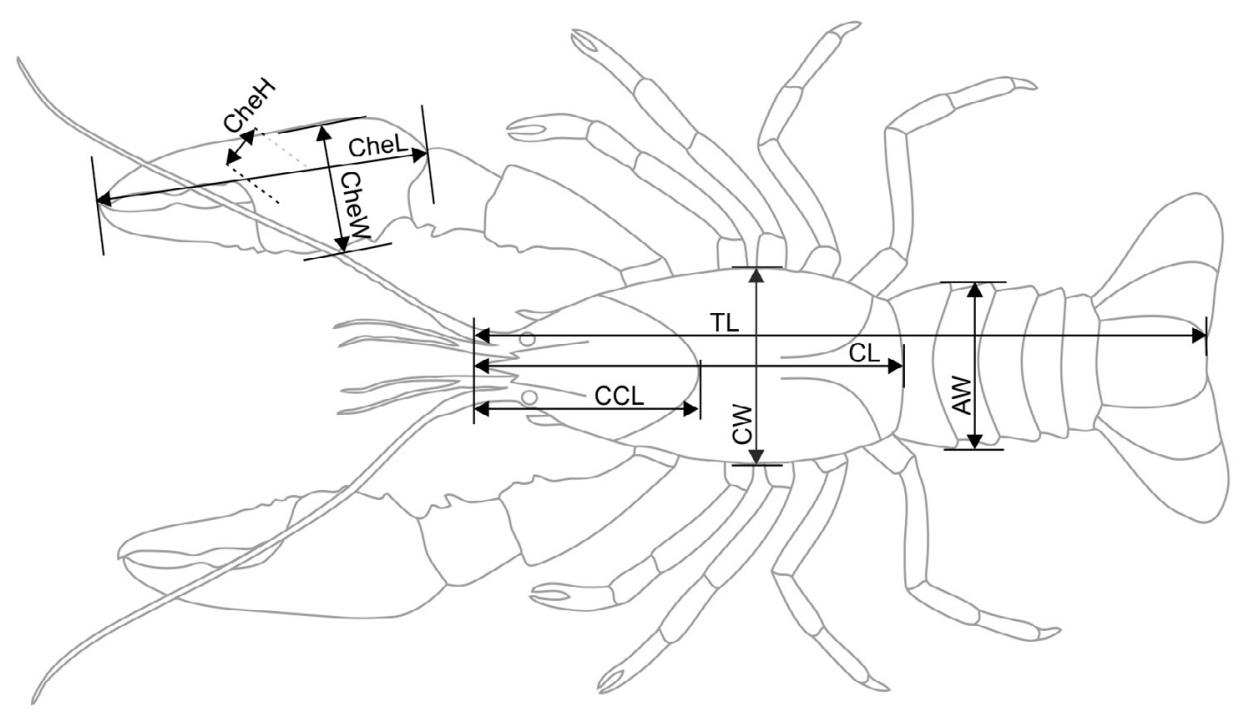

Figure 2

The measurements used for this study: TL...total body length, CL. . carapace length, CCL...length of rostro-cervical part of the carapace, CW. . .carapace width, AW. . .abdomen width, CheL. . .chelae length, CheW. . .chelae width, CheH. ..chelae height.

observed in individuals longer than $30 \mathrm{~mm}$ : the total body length between the rostrum and the end of the telson (TL), the carapace length $(\mathrm{CL})$, the length of the rostro-cervical part of the carapace (CCL), the carapace width (CW), the abdomen width (AW), the chela length (CheL), the chela width (CheW), and the chela height $(\mathrm{CheH})$. The measurements are shown in Figure 2.

The measured data were further analysed in their relative forms as ratios to carapace length or chelae length (in \%). Such a transformed relative data were evaluated separately for all 203 males and 205 females. A second set of evaluations included only individuals no longer than $45 \mathrm{~mm}$ (29 females, 22 males) to find possible differences at the stage preceding the puberty moult.

Evaluating these data, basic descriptive statistics (mean, minimum, maximum and standard deviation) were obtained separately for males and females. Sexual dimorphism in juveniles and adults was examined in observed measurements using the non-parametric Kruskal-Wallis Analysis of Variance (ANOVA) as the data were not normally distributed.

Moreover, possible allometric growth was studied. In this study, the allometry is seen as relationships between body measurements and changes in the relative proportions of these measurements with changes in absolute size (Huxley, 1932). The relative morphometric data mentioned above (i.e. $\mathrm{CCL} \times \mathrm{CL}, \mathrm{CW} \times \mathrm{CL}, \mathrm{AW} \times \mathrm{CL}, \mathrm{CheL} \times \mathrm{CL}, \mathrm{CheW} \times \mathrm{CheL}, \mathrm{CheH} \times$ $\mathrm{CheL}$ ) were evaluated in the context of $\mathrm{CL}$ (or CheL) using simple linear regression, as also used, e.g., by Streissl and Hödl (2002). Slopes of estimated lines were tested by means of coefficients of determination and $t$-tests. The significant differences from the zero slope were considered as allometric; positive allometry if the slope was higher than zero and opposite. All tests were evaluated at a significance level of $5 \%$ using the NCSS 9 software package.

\section{RESULTS}

The morphometry of 408 collected individuals from 14 streams in 2012-2013 was analysed (see Table I for more detailed information). The total body lengths of females varied between 30 and $94.8 \mathrm{~mm}$ with a mean value of 64.8 . $\mathrm{mm}$. Males were significantly longer (Kruskal 
Table I

Numbers of individuals from the observed streams used for study.

\begin{tabular}{|l|c|c|}
\hline Stream & Females & Males \\
\hline 1. Medvědí brook & 14 & 15 \\
2. a left tributary of Novosedlský brook & 16 & 14 \\
3. Zubřina & 14 & 16 \\
4. Chocenický brook & 19 & 11 \\
5. Přešínský brook & 11 & 18 \\
6. Rakovský brook & 17 & 14 \\
7. Chejlava & 15 & 16 \\
8. Bzovský brook & 13 & 15 \\
9. Luční brook (Giant Mountains) & 17 & 12 \\
10. Huníkovský brook & 18 & 12 \\
11. Vrbový brook & 8 & 14 \\
12. Valdecký brook & 13 & 17 \\
13. Luční brook (Bohemian Highlands) & 16 & 13 \\
14. Trojhorský brook & 14 & 16 \\
\hline Total & 205 & 203 \\
\hline
\end{tabular}
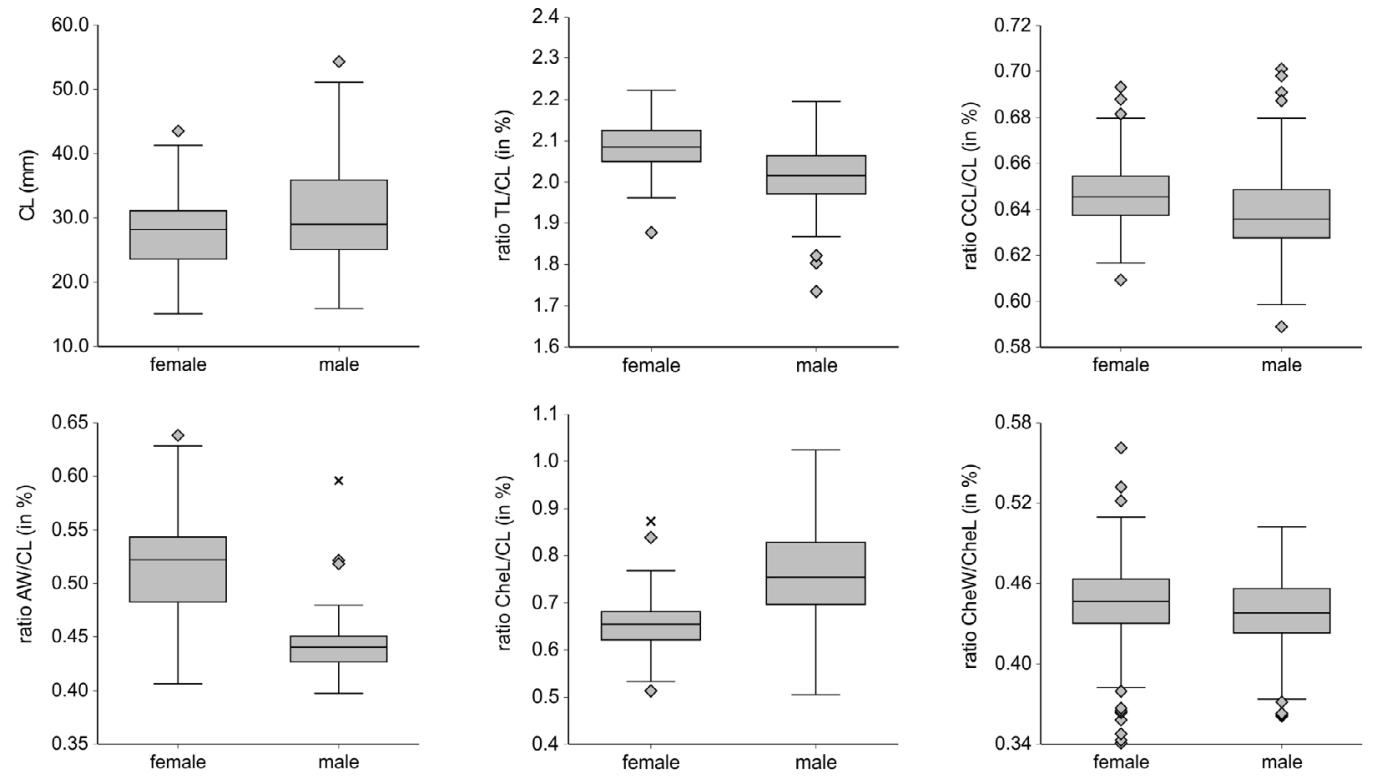

\section{Figure 3}

Box plots describing sexual dimorphism in the stone crayfish (A. torrentium) in the Czech Republic (median, inter-quartile range (IQR), the largest value/the smallest value smaller/bigger than 1.5 times $I Q R$, extremes), from top left: 1. carapace length (CL, in $\mathrm{mm})$, 2. total body length vs. carapace length (ratio TL/CL, in \%), 3. length of rostro-cervical part of caparace vs. carapace length (ratio CCL/CL, in \%), 4. abdomen width vs. carapace length (ratio AW/CL, in \%), 5. chelae length vs. carapace length (ratio CheL/CL, in \%), 6. chelae width vs. chelae length (ratio CheW/CheL, in \%).

Wallis ANOVA, $H=3.86, P=0.049$ ) and their length ranged from $32.4 \mathrm{~mm}$ up to $103.6 \mathrm{~mm}$. The mean length of males was $71.2 \mathrm{~mm}$ (see Figure 3). The largest individuals (including one specimen exceeding $100 \mathrm{~mm}$ in length) were found in Luční brook in the Giant Mountains.

Most of the observed morphological features differed between sexes. Males had relatively longer total body length $(H=110.461, P<0.001)$, whereas the rostro-cervical part of females' carapace, related to the carapace length, was larger $(H=34.074, P<0.001)$. Carapace widths of males and females did not differ $(H=0.006, P=0.936)$, however, the females' abdomens were significantly wider $(H=223.538, P<0.001)$. Males had relatively longer chelae than females $(H=169.756, P<0.001)$. Females chelae were wider, compared to 
Table II

Basic descriptive statistics (mean, SD. . . standard deviation, min. . . minimum, max. . maximum) of selected relative measurements (related to carapace length or chelae length) of the stone crayfish (A. torrentium) in the Czech Republic (TL. . . total length, CL. . . carapace length, CCL. . . length of rostro-cervical part of carapace, AW. . . abdomen width, CheL. . . chelae length, CheW. . . Chelae width, CheH. . . chelae heigth).

\begin{tabular}{|l|c|c|c|c|c|c|c|c|}
\multicolumn{1}{c|}{} & \multicolumn{4}{|c|}{ Females } & \multicolumn{4}{c|}{ Males } \\
\cline { 2 - 9 } \multicolumn{1}{c|}{} & Mean & SD & Min & max & mean & SD & min & max \\
\hline TL $\times$ CL & 2.087 & 0.054 & 1.877 & 2.222 & 2.012 & 0.071 & 1.734 & 2.195 \\
$\mathbf{C C L} \times \mathbf{C L}$ & 0.646 & 0.014 & 0.609 & 0.693 & 0.637 & 0.018 & 0.589 & 0.701 \\
$\mathbf{C W} \times \mathbf{C L}$ & 0.493 & 0.024 & 0.435 & 0.568 & 0.494 & 0.026 & 0.421 & 0.573 \\
$\mathbf{A W} \times \mathbf{C L}$ & 0.516 & 0.045 & 0.406 & 0.693 & 0.442 & 0.022 & 0.397 & 0.596 \\
$\mathbf{C h e L} \times \mathbf{C L}$ & 0.654 & 0.0473 & 0.513 & 0.873 & 0.764 & 0.097 & 0.504 & 1.024 \\
$\mathbf{C h e W} \times \mathbf{C h e L}$ & 0.443 & 0.031 & 0.341 & 0.561 & 0.437 & 0.027 & 0.361 & 0.502 \\
$\mathbf{C h e H} \times \mathbf{C h e L}$ & 0.268 & 0.024 & 0.198 & 0.378 & 0.27 & 0.023 & 0.204 & 0.365 \\
\hline
\end{tabular}

the chelae length $(H=6.55, P=0.010)$. No sexual dimorphism in chelae relative height was proven $(H=1.741, P=0.187)$. Detailed information is presented in Table II and Figure 3.

The data concerning only individuals before the puberty moult were evaluated separately (see Figure 4). The analysis of variance found no differences between the sexes at this age level in most measurements apart from the relative abdomen width and the chelae length. Also the relative abdomen width was larger in immature females (Kruskal Wallis ANOVA, $H=19.1138$, $P<0.001)$, and chelae were longer in young males $(H=7.22, P=0.005)$.

Similarly to the characters mentioned above for the sexual dimorphism, most observed measurements showed allometric growth also separately within both sexes. The relation between the carapace length and the total body length refers to the negative allometry in males (linear equation $2.196-0.0060 \times \mathrm{CL}, R^{2}=0.438, t=-12.513, P<0.001$ ), and also in females (linear equation $2.138-0.0019 \times \mathrm{CL}, \mathrm{R}^{2}=0.039, t=-2.882, P=0.004$ ), and to the positive allometry of the relative width of carapace in males (linear equation $0.427+0.0011 \times \mathrm{CL}$, $R^{2}=0.350, t=10.370, P<0.001$ ), as well as in females (linear equation $0.432+0.0011 \times \mathrm{CL}$, $\left.R^{2}=0.272, t=8.702, P<0.001\right)$. The negative allometric growth of the rostro-cervical part of the carapace was proven in both sexes (linear equation $0.671-0.0005 \times \mathrm{CL}, R^{2}=0.181$, $t=-6.659, P<0.001$ for males; linear equation $0.672-0.0005 \times \mathrm{CL}, R^{2}=0.139, t=-5.731$, $P<0.001$ for females).

The positive allometry of the relative abdomen width was calculated only in females. The relationship for females is expressed by the linear equation $0.1840+0.0023 \times \mathrm{CL}\left(R^{2}=0.356\right.$, $t=10.575, P<0.001)$. In males, abdomen had isometric growth $(\mathrm{AW}=0.4546-0.0004 \times \mathrm{CL}$; $\left.R^{2}=0.0188, t=-1.953, P=0.055\right)$.

Chelae allometric growth is most noticeable in males, but also seen in females. Chelae length of both sexes showed strong positive allometric growth, most evident among males (linear equation $0.437+0.01070 \times \mathrm{CL}, R^{2}=0.745, t=24.192, P<0.001$ ) but also significant in females (linear equation $0.543+0.004 \times \mathrm{CL}, R^{2}=0.233, t=7.818, P<0.001$ ). Differences between the sexes in the allometric growth of the chelae width were also found. Whereas in larger males the chelae were narrower (linear equation $0.459-0.0001 \times \mathrm{CL}, R^{2}=0.0458, t=$ -3.09, $P=0.002$ ) and lower (linear equation $0.295-0.0008 \times \mathrm{CL}, R^{2}=0.076, t=-4.045, P<$ 0.001 ) in relation to the chela lenght, in females the chelae width/length ratio showed positive allometric growth (linear equation $0.42+0.0008 \times \mathrm{CL}, R^{2}=0.0231, t=2.14, P=0.032$ ) and chelae height/length ratio grew similarly to the carapace length growth ( $t=-1.2730$, $P=0.205)$. The above described equations are depicted in Figure 5.

\section{DISCUSSION}

In this study, the total body length and seven other size characters were evaluated in a large series of stone crayfish specimens from populations covering its overall range of distribution 

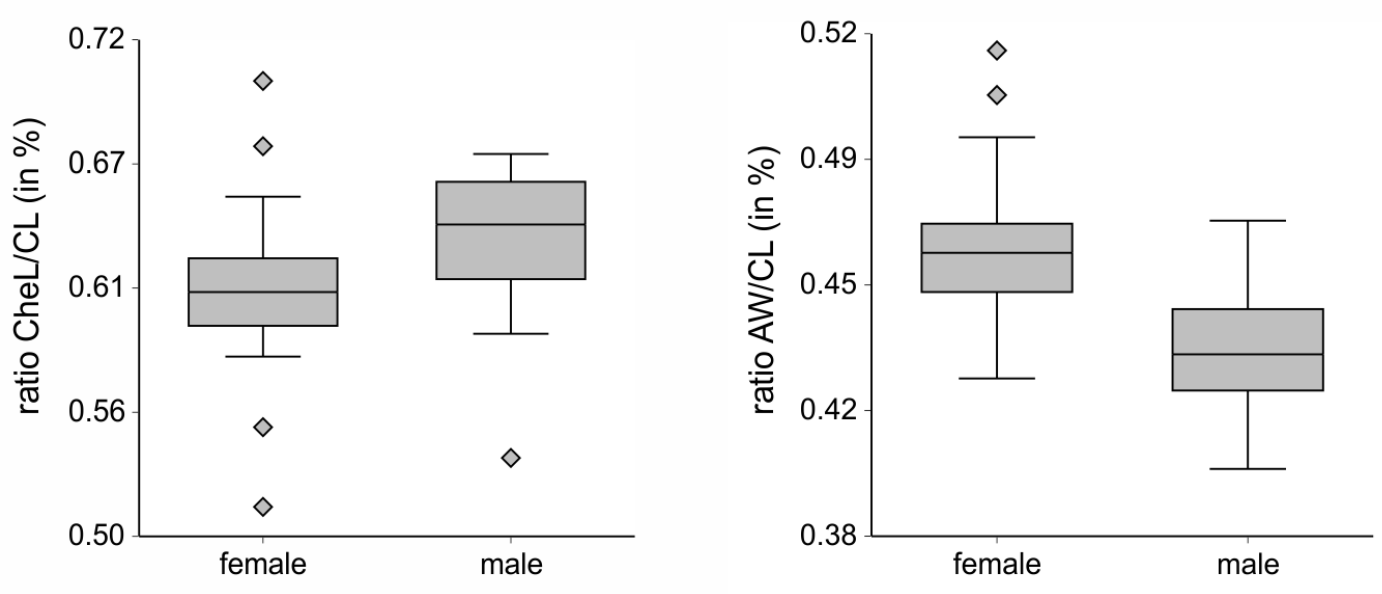

\section{Figure 4}

Box plots describing sexual dimorphism in juveniles of the stone crayfish (A. torrentium) in the Czech Republic (median, inter-quartile range (IQR), the largest value/the smallest value smaller/bigger than 1.5 times IQR, extremes), from left: 1. abdomen width vs. carapace length $(A W \times C L)$, 2. chelae length vs. carapace length (CheL $\times C L)$.

in the Czech Republic. The body length of the largest male was $103.6 \mathrm{~mm}$, the largest female $94.8 \mathrm{~mm}$. Whereas the maximum body length of females is in agreement with previously reported data (Papadopol and Diaconu, 1987; Streissl and Hödl, 2002; Vlach et al., 2009a; Pârvulescu, 2010), the males exceeding a length of $100 \mathrm{~mm}$ are uncommon in their entire distribution range (Maguire et al., 2002; Streissl and Hödl, 2002; Pârvulescu, 2010). In the Czech Republic, such large males often occur only in the Luční brook in the Giant Mountains (Vlach et al., 2009a). It can be explained by the assumption that this population belongs to a different lineage originating from the Balkan Peninsula (Pešek, 2013).

The observed differences between sexes in crayfish body length have been previously reported (e.g. Papadopol and Diaconu, 1987; Streissl and Hödl, 2002; Vlach et al., 2009a; Pârvulescu, 2010). This fact is connected with social behaviour - males fight among themselves during their reproductive season and larger males are more successful. This is considered as a selective advantage in the reproductive process (Woodlock and Reynolds, 1988; Svensson and Gydemo, 1996).

Apart from differences in body length, differences between the sexes in morphological features resulted from allometric growth were proven in this study. Size and shape of the carapace is often considered as a typical sexual dimorphism in crayfish. Within this research, males were found to possess relatively longer carapace than females. Whereas the body length growth in females was isometric (related to the carapace length), the body length of males grew with strongly negative allometry, even in adults, and carapace width showed positive allometry in both sexes. These findings are consistent with other works (Streissl and Hödl, 2002; Pârvulescu, 2010). Changes in growth of carapace could be explained as a consequence of changing etho-ecological and physiological demands. Carapaces of juveniles in lotic waters are commonly narrow as they need to resist the water current easily and to find shelter among gravel (Scalici et al., 2010), the preferred substrata at this age stage (Vlach et al., 2009b). Although Curra (1964) mentioned negative allometry in gill growth in crayfish from the genus Austropotamobius, growing gills and other organs need more space resulting in positive allometry of carapace traits (Scalici et al., 2010; Haddaway et al., 2012). On the contrary, we did not found differences in the relative carapace width between sexes, otherwise reported by Streissl and Hödl (2002), or Pârvulescu (2010).

Another typical distinction between the sexes is the abdomen width. In this study, the wider abdomen of females was described, similarly to Grandjean and Souty-Grosset (2000) and 

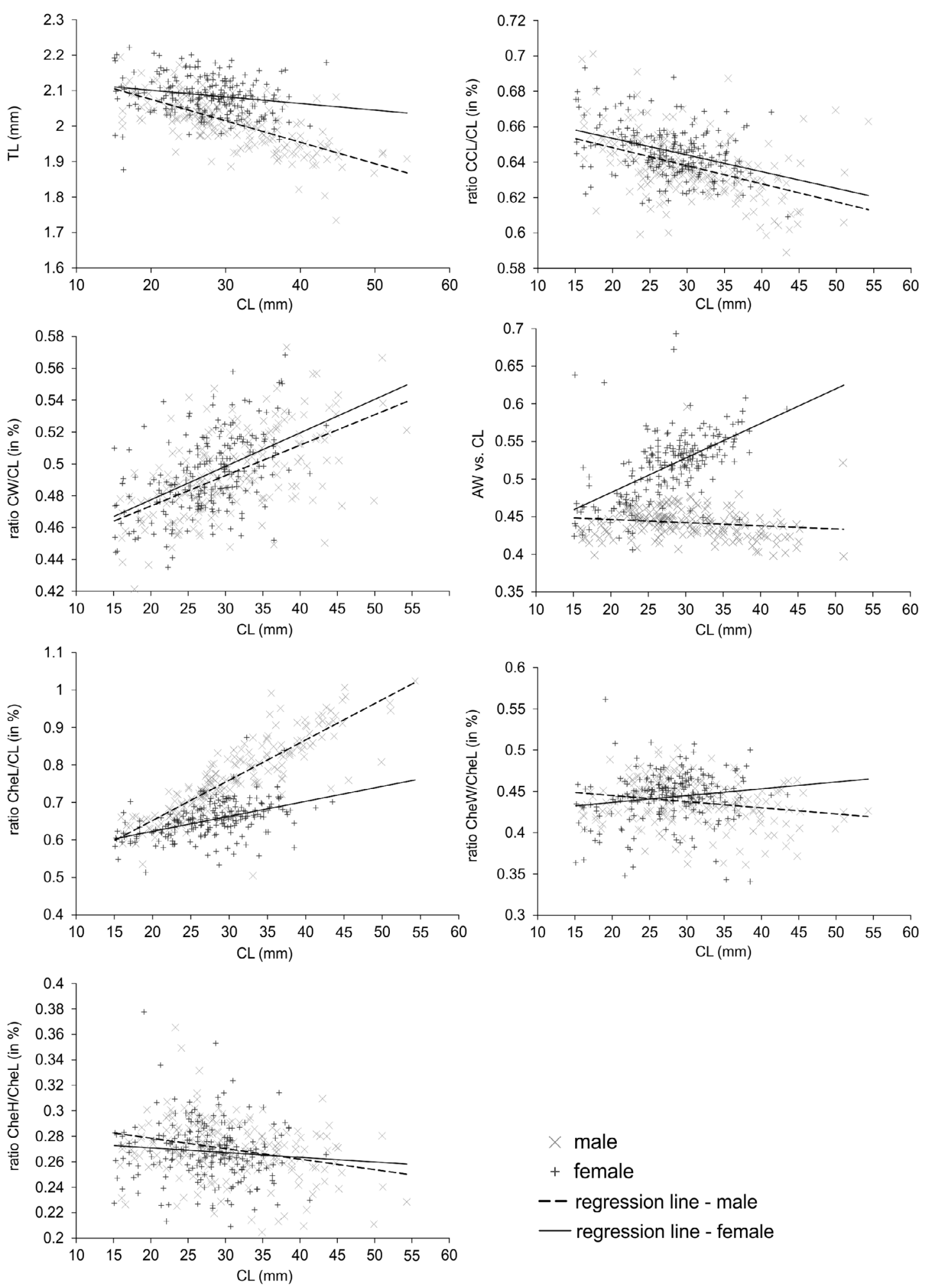

\section{Figure 5}

Relationships between relative measurements and carapace length (or chelae length) of the stone crayfish (A. torrentium) in the Czech Republic, from top left: 1. total body length (relatively to carapace length $-T L \times C L$ ), 2. length of rostro-cervical part of the carapace (rel. to carapace length - ratio CCL/CL $\times C L$ ), 3. carapace width (rel. to carapace length $-\mathrm{CW} / \mathrm{CL} \times \mathrm{CL}$ ), 4. abdomen width (rel. to carapace length $A W / C L \times C L)$, 5. chelae length (rel. to carapace length $-C h e L / C L \times C L)$, 6. chelae width (rel. to chelae length - CheW/CheL $\times$ CheL), 6. chelae height (rel. to chelae length - CheW/CheL $\times$ CheL). 
Pârvulescu (2010). Moreover, females showed positive allometric abdomen width growth, whereas such a growth in males was isometric. This finding corresponds with the often demonstrated fact that a larger abdomen increases the capacity for carrying eggs, improves egg attachment and as a result increases the whole reproductive success (Grandjean et al., 1997; Maguire et al., 2002; Reynolds, 2002; Maguire et al., 2005). Although Thomas and Ingle (1971) and Lowery (1988) mentioned the positive allometry in the abdomen width only in females after reaching sexual maturity, we found, similarly to Grandjean et al. (1997), that significant sexual dimorphism in abdomen width already exists before the pubertal moult.

The proportions of the chelae (claws) are often considered as one of the most important features of sexual dimorphism. As reported in many works (e.g. Stein, 1976; Grandjean and Souty-Grosset, 2000; Streissl and Hödl, 2002; Pârvulescu, 2010), crayfish males have relatively longer chelae than females. Many studies also described relatively wider males' chelae (Grandjean et al., 1997; Pârvulescu et al., 2009; Pârvulescu, 2010). We consider that this impression of relatively wider males' claws is due to by their generally larger size (length).

In this study, the males' chelae are evaluated as 'narrower' than females' ones. Chelae typically grow disproportionately to other crayfish dimensions. In this study, chelae showed a positive allometric length growth in both sexes, although much steeper in males. This phenomenon is easy to explain; as already mentioned above, it is primarily associated to social behaviour of crayfish. Males use chelae when competing for females; larger chelae are profitable in such a situation. Moreover, larger chelae enable big males to mate with larger, more fertile, females with a wider abdomen (see above). Thus, bigger chelae increase reproductive success (e.g. Stein, 1976; Vilanelli and Gherardi, 1998).

There are various statements concerning allometric chelae growth in juvenile and adult individuals in the above mentioned works. These contributions are mostly in compliance with the fact that after puberty moult (e.g. after reaching sexual maturity) the chelae length growth rapidly increases, especially in males (Stein, 1976; Grandjean and Souty-Grosset, 2000; Streissl and Hödl, 2002; Pârvulescu et al., 2009). Moreover, some authors (e.g. Thomas and Ingle, 1971; Stein, 1976; Lowery, 1988) suggested that the chelae length of various crayfish species can be considered as diverging between the sexes only after reaching maturity. This was also stated by Streissl and Hödl (2002) for A. torrentium. In the present work, significant differences between sexes were proven also in juveniles' chelae length (as well as in abdomen width). Unlike other works, negative allometric growth of chelae width (in both sexes) and height (in males) was proven. However this incompatibility is explained by the different methodology used; we considered chelae width and height relatively to their length, whereas above mentioned works related these measurements to the carapace length (or the total body length).

In this study, most observed morphological traits showed a wide range of variability. This variability is an evolutionary strategy based on various genotypes (Brian et al., 2006, Henryon et al., 1989; Jones et al., 2000; Lutz and Wolters, 1989) or variations of the same genotype (Ghia et al., 2006) allowing an organism to alter its morphology or behaviour (Haddaway et al., 2012). In the Czech Republic, we should consider more than only one genetic lineage; together with isolated populations from the Danube or Elbe watersheds, a special position is occupied by the stone crayfish population from Luční brook in the Giant Mountains which probably was introduced from the Balkan Peninsula (Pešek, 2013).

In conclusion, we analysed an extensive series of stone crayfish specimens across the entire distribution of this species in the Czech Republic. Several results correspond with other published observations, nevertheless there are some additional findings: (1) the relative abdomen width and chelae length show sexual dimorphism already at the juvenile stage; (2) no differences was found between sexes in the relative carapace width; (3) the positive allometry has been confirmed in the relative abdomen width in females; (4) the positive allometry of chelae width and height (related to their length) was proven for females (evidently resulting from slower growth of chelae length in females than in males). 


\section{ACKNOWLEDGEMENTS}

We thank for language correction provided by Julian D. Reynolds, and to two anonymous reviewers for valuable comments and recommendations. This study was supported by the University of West Bohemia, project SGS-2014-059 named "Differences in the morphology of the stone crayfish among population groups of different origin in the Czech Republic".

\section{REFERENCES}

Bertocchi S., Brusconi S., Gherardi F., Buccianti A. and Scalici M., 2008. Morphometrical characterization of the Austropotamobius pallipes species complex. J. Nat. Hist., 42, 31-32.

Brian J.V., Fernandes T., J., L.R. and Todd P.A., 2006. Patterns of morphological and genetic variability in UK populations of the shore crab, Carcinus maenas Linnaeus, 1758 (Crustacea: Decapoda: Brachyura). J. Exp. Mar. Biol. Ecol., 329, 47-54.

Curra R.A., 1964. A Case of Negative Allometry in Austropotamobius Gill Growth. Nature, 201, 842-843.

Duriš Z., Kozák P., Policar T. and Theimer J., 2001. The stone crayfish Austropotamobius torrentium (Schrank) in the Czech Republic. Čas. Sl. Zem. Muz. Opava (A), 50 (Suppl.), 85-93 [in Czech; English abstract].

Endrizzi S., Bruno M.C. and Maiolini B., 2013. Distribution and morphometry of native and alien crayfish in Trentino (Italy). J. Limnol., 72, 343-360.

Figiel J.C. and Miller G.L., 1995. The frequency of chela autonomy and its influence on the growth and survival of the crayfish Procambarus clarkii (Girard, 1852) (Decapoda, Cambaridae). Crustaceana, $68,472-483$.

Gayon J., 2000. History of the Concept of Allometry. Amer. Zool., 40, 748-758.

Ghia D., Nardi P.A., Negri A., Bernini F., Bonardi A., Fea G. and Spairani M., 2006. Syntopy of $A$. pallipes and A. italicus: genetic and morphometrical investigations. In: Gherardi F. and Souty-Grosset C. (eds.), European crayfish as heritage species - linking research and management strategies to conservation and socio-economic development. Bull. Fr. Pêche. Piscic. 380-381, 1001-1018.

Grandjean F. and Souty-Grosset C., 2000. Genetic and morphological variation in the endangered crayfish species, Austropotamobius pallipes (Lereboullet) (Crustacea, Astacidae) from the PoitouCharentes region (France). Aquat. Sci., 62, 1-19.

Grandjean F., Romain D., Avila-Zarza, C., Bramard, M., Souty-Grosset, C. and Mocquard, J.P., 1997. Morphometry, sexual dimorphism and size at maturity of the white-clawed crayfish Austropotamobius pallipes pallipes (Lereboullet) from a wild French population at Deux-Sèvres (Decapoda, Astacidea). Crustaceana, 70, 31-44.

Haddaway N.R., Mortimer R.J.G., Christmas M., Grahame J.W. and Dunn A.M., 2012. Morphological diversity and phenotypic plasticity in the threatened British white-clawed crayfish (Austropotamobius pallipes). Aquatic Conserv: Mar. Freshw. Ecosyst., 22, 220-231.

Henryon M., Purvis I.W. and Berg P., 1989. Definition of a breeding objective for commercial production of the freshwater crayfish, marron (Cherax tenuimanus). Aquaculture, 173, 179-195.

Huxley J.S., 1932. Problems of relative growth. Methuen \& Co. Ltd., London, 275 p.

Jones C.M., McPhee C.P. and Ruscoe I.M., 2000. A review of genetic improvement in growth rate in redclaw crayfish Cherax quadricarinatus (von Martens) (Decapoda: Parasticidae). Aquac. Res., 31, 61-67.

Klingenberg Ch.P., 1998. Heterochrony and allometry: the analysis of evolutionary change in ontogeny. Biol. Rev., 73, 79-123.

Kouba A., Petrusek A. and Kozák P., 2014. Continental-wide distribution of crayfish species in Europe: update and maps. Knowl. Manag. Aquat. Ecosyst., 413, 05.

Kozák P., Ďuriš Z. and Policar T., 2002. The stone crayfish Austropotamobius torrentium (Schrank) in the Czech Republic. Bull. Fr. Pêche Piscic., 367, 707-713. 
Kozák P., Ďuriš Z., Petrusek A., Buřič, M., Horká I., Kouba A., Kozubíková, E. and Policar, T., 2013, 2015. Biology and Culture of Crayfish. FFPW, Univ. S. Bohemia, 418 p. [2013, in Czech; Engl. abstr.], 456 p. [2015, extended English transl.].

Lowery, R.S., 1988. Growth, Moulting and Reproduction. In: Holdich, D.M. and Lowery, R.S. (eds.). Freshwater Crayfish: Biology, Management and Exploitation. Chapman \& Hall, London, 83-113.

Lutz C.G. and Wolters R.W., 1989. Estimation of hereditabilities for growth, body size, and processing traits in red swamp crayfish, Procambarus clarkii (Girard). Aquaculture, 78, 21-33.

Maguire I. and Klobučar G.I.V., 2009. Morphological characteristics of stone crayfish from " ŽumberakSamoborsko gorje“ Nature Park. In: Kouba A. (ed.), Regional European Crayfish Workshop: Future of Native Crayfish in Europe - Abstract Book University of South Bohemia in České Budějovice, Písek, 35-35.

Maguire I., Erben R., Klobučar G.I.V. and Lajtner J., 2002. A year cycle of Austropotamobius torrentium (Schrank) in streams on Medvednica mountain (Croatia). Bull. Fr. Pêche Piscic., 367, 943-957.

Maguire I., Klobučar G.I.V. and Erben R., 2005. The relationship between female size and egg size in the freshwater crayfish Austropotamobius torrentium. Bull. Fr. Pêche Piscic., 376-377, 777-785.

Papadopol M. and Diaconu G., 1987. Contributions to the knowledge of the morphology of the astacid crayfishes from Romania. Trav. Mus. Natl. Hist. Nat. Grigore Antipa, 314, 5-6.

Pârvulescu L., 2010. Comparative biometric study of crayfish populations in the Anina Mountains (SW Romania) hydrographic basins. Stud. Univ. Babes. Bolyai. Biol., 1, 3-15.

Pârvulescu L., Petresku A. and Petrescu I., 2009. Abnormal colors and shapes of the body and the appendages of Austropotamobius torrentium (Schrank, 1803) in Romania. Crayfish News, 31, 6-8.

Pešek P., 2013. Genetic diversity of stone crayfish Austropotamobius torrentium in marginal areas of its distribution. MSc. thesis, Faculty of Science, Charles University in Prague, 57 p. [in Czech; English summary].

Reynolds J.D., 2002. Growth and reproduction. In: Holdich, D.M. (ed.), Biology of Freshwater Crayfish. Blackwell Science, Oxford, 152-192.

Scalici M., Macale D. and Gibertini G., 2010. Allometry in the ontogenesis of Austropotamobius pallipes species complex (Decapoda: Astacidae): The use of geometric morphometrics. Ital. J. Zool., 77, 296-302.

Sint D., Via J.D. and Füreder L., 2005. Morphological variations in Astacus astacus L. and Austropotamobius pallipes (Lereboullet) populations. Bull. Fr. Pêche Piscic., 376-377, 637-652.

Souty-Grosset C., Holdich D.M., Noël P.Y., Reynolds J.D. and Haffner P. (eds.), 2006. Atlas of Crayfish in Europe. Patrimoines Naturels 64. Muséum National d'Histoire Naturelle, Paris.

Štambergová M., Svobodová J. and Kozubíková E., 2009. Crayfish in the Czech Republic. Nat. Conserv. Agency, Czech Rep., Prague, 255 p. [in Czech; Engl. abstr.].

Stein R.A., 1976. Sexual dimorphism in crayfish chelae, functional significance linked to reproductive activities. Can. J. Zool., 54, 220-227.

StreissI F. and Hödl W., 2002. Growth, morphometrics, size at maturity, sexual dimorphism and condition index of Austropotamobius torrentium Schr. Hydrobiologia, 477, 201-208.

Svensson M. and Gydemo R., 1996. Mating capacity in male noble crayfish, Astacus astacus, under laboratory conditions. Freshwater Crayfish, 9, 311-318.

Thomas W. and Ingle R., 1971. The nomenclature, bionomics and distriobution of the crayfish, Austropotamobius pallipes (Lereboullet) (Crustacea, Astacidae) in the British Isles. Essex Naturalist, 32, 349-360.

Vilanelli F. and Gherardi F., 1998. Breeding in the crayfish, Austropotamobius pallipes: mating patterns, mate choice and intermale competition. Freshw. Biol., 40, 305-315.

Vlach P., Hulec, L. and Fischer D., 2009a. Recent distribution, population densities and ecological requirements of the stone crayfish (Austropotamobius torrentium) in the Czech Republic. Knowl. Manag. Aquat. Ecosyst., 384-395, 13.

Vlach P., Fischer D. and Hulec L., 2009b. Microhabitat preference of the stone crayfish Austropotamobius torrentium (Schrank, 1803). Knowl. Manag. Aquat. Ecosyst., 384-395, 15.

Vlach P., Svobodová J. and Fischer D., 2012. Stone crayfish in the Czech Republic: how does its population density depend on basic chemical and physical properties of water? Knowl. Manag. Aquat. Ecosyst., 407, 05. 
Woodlock B. and Reynolds J.D., 1988. Laboratory breeding studies of freshwater crayfish, Austropotamobius pallipes (Lereboullet). Freshw. Biol., 19, 71-78.

Zekić Ž., Abaza A. and Pelo A., 2013. Morphological and environmental characterization of population of white-clawed crayfish - Autropotamobius pallipes (Lereboullet, 1858) in Buna River (Mostar Minucipality, Bosnia and Herzegovina). Natura Montenegrina, 12, 863-874.

Cite this article as: P. Vlach and L. Valdmanová, 2015. Morphometry of the stone crayfish (Austropotamobius torrentium) in the Czech Republic: allometry and sexual dimorphism. Knowl. Manag. Aquat. Ecosyst., 416, 16. 